\title{
The Relationship between Sports Students Exchange Experience and English Learning Motivation of Unnes and UITM Students
}

\author{
Setya Rahayu ${ }^{1}$, Fatona Suraya ${ }^{2}$, Ani Mazlina Dewi Mohamed ${ }^{3}$, Soegiyanto ${ }^{4}$, Mawarn \\ Mohamed $^{5}$, Ikhwan Budi ${ }^{6}$, Danti Putri Subagyo ${ }^{7}$, Imam Syihabudin ${ }^{8}$, Rahmat Septianto ${ }^{9}$ \\ \{setyarahayu@mail.unnes.ac.id ${ }^{1}$, suraya@mail.unnes.ac.id ${ }^{2}$, anima107@ salam.uitm.edu.my ${ }^{3}$ \} \\ Universitas Negeri Semarang, Semarang, Indonesia ${ }^{1,2,4}$ \\ Universiti Teknologi MARA, Shah Alam, Malaysia ${ }^{3,5}$
}

\begin{abstract}
Sports students exchanges has been widely popular due to its benefits for students, one of which is to improve their English skills. In the Faculty of Sports Science, UNNES and Faculty of Physical Education and Health, UiTM, many students who are going abroad mostly in Asia use English, as a lingua franca, to communicate with others whom first language is not English. However, limited studies have discussed on the relationship of joining exchanges program toward the students' motivation in learning English. This study will be conducted to explain the relationship between participating and non-participating in sports students exchange programs toward the students' motivation in learning English. The subjects are sports students from UNNES and UiTM. A non-experimental research design with a causal-comparative method will be conducted with a set of questionnaires and an interview rubric as the instrument. The data will be analyzed statistically and will be explained using a descriptive quantitative approach.
\end{abstract}

Keywords: sports students, students exchange, motivation, English as a lingua franca, English skills..

\section{Introduction}

A student exchange program has gained a lot of traction in universities worldwide [1], as the program proposes several benefits either for students or for the institution. Research discussed several benefits of student exchange program namely students have the opportunity of learning and embracing themselves with a new language [2], [3]; students get social and cultural experiences, students become more multiculturism [4], [5], getting a new understanding of the country they visited, and building international relationship among students [2], [3], [6]. Interestingly, students who experience exchange study develop beyond their area of study and able to embrace themselves in an international and intercultural interaction [7], [8]. The exchange program is also the best way to become proficient at speaking a foreign language, experience different teaching styles, and build an International Resume [9], [10]. An International collaboration project is also great in improving students' cultural competency skills and basic networking [7], [11].

Faculty of Sports Science (FSS), Universitas Negeri Semarang (UNNES) is one of the Faculty in UNNES, which shows a high commitment to Internationalization [12]. Its internationalization history is closely tied with the history of Aucpess (ASEAN Universities 
Conference on Physical Education and Sport Sciences). AUCPESS started in 2011[13]. Since July eight, 2014, AUCPESS expanded its scope and upgraded its name to be ACPES (ASEAN Council of Education and Sport) to accommodate many sports' community aspirations and expressions. The first ACPES conference in 2015, was hosted by Universitas Negeri Negeri Semarang Indonesia. Nowadays, ACPES has networking eleven universities from five countries namely Thailand, Malaysia, Indonesia, Singapore, and Philippines. Its member universities managed various activities, namely hosting international conferences, joint research programs, joint publication programs, lecturer exchange programs, student exchange programs, community services, and internship exchange programs, to name but a few. Upon those many Internationalization programs, one of which is a student exchange program.

In line with the Faculty of Sports Science, UNNES, the Faculty of Physical Education and Health (FPEH), Universiti Teknologi Mara (UiTM), Malaysia, also very active in expanding its International network. It also one of ACPES active member and has been hosted some international program. The 3rd ACPES was hosted by UiTM in collaboration with UPM, Malaysia in 2018. Besides, The faculty opens for inbound and outbound program with some countries namely Japan, Malaysia, Thailand, South Korea, Philippines, Cambodia, China, and Indonesia [14].

The Sports Student Exchange Program (SSE) is a program where students from partner universities from sport-related majors come to our faculty and vice versa. The student exchange program is a reciprocal activity between two universities or more to exchange students for a certain period. Hinojo_lucena in his research about International collaboration, found that the collaboration between also countries improve learning and relevance for exchange information [15]. It also teaches different methods and systems in learning specific knowledge [15], [16].

The exchange students from various country sometime hard to communicate using country dialect, thus English role as a lingua Franca to connect this multiculturism background of the students. English as a lingua franca is the use of English between speakers of various first language for whom English is the only communicative medium of choice and frequently the lone alternative [17]. English language is highly needed to raise the value of our graduate in the International level [18]. Therefore, the benefit of exchange program in motivating the students to communicate using the English language is highly valued.

As the coming of industrial revolution 4.0, the demand of Sports Scientist who are able to communicate well in English is getting higher. The present of Asean School Games on July 2019 has shown that the event needed more than 100 sport science student volunteers and lectures to help as the event organizer, judges, as well as guides for foreign athletes and sports organizer [19]. Previous event of ASEAN Games 2018 held in Jakarta and Palembang, Indonesia needed over than 10.000 volunteer across Indonesia [20] to help as protocol assistant, assistant for National Olympic Committee (NOC), Liaison office and work force [21]. In addition to that, Sports Science Faculty is also preparing for ASEAN University Network- Quality Assurance which forced our faculty to broaden its network minimum in ASEAN level. Here, English roles as a medium of instruction between countries on their collaboration which includes students exchange, joint degree, joint research, joint internship, guest lectures, to name but a few. It goes without saying that, preparing a good English in Sports science is required to equip the students with soft skill needed either during their academic study or for their job market.

Research by Suraya et.al mentioned that students of sports science faculty who have joined an exchange program tend to repeat their experience by joining another exchange program whenever offer[22]. They also more active in some international events compared to 
those who never joined the program. An observation was conducted in UiTM, students who have previously involved in exchange program were more supportive toward any internationalization program in the university. However, there is a minimum study which discuss the relationship between the exchange program toward the students motivation to learn the English language, especially the English as lingua Franca [23]. Therefore, this study aims to fill the gap by asking question if there is any difference between students who joined exchanges program and those who did not join exchange program with respect to their motivation in learning English for the students of UNNES, Indonesia and UiTM, Malaysia. The quenstions guiding the study is; is there any difference in students motivation in learning English between FSS, UNNES and FPEH, UiTM for students who joined exchanges program?

This research aims to understand the difference between FSS, UNNES and FPEH, UiTM students motivation in learning English for those who joined exchanges program.

\section{Method}

This is a non-experimental research design with a causal-comparative approach. It aims to determine if exchanges experience toward English learning motivation experience differed among students who participated in students exchange and did not participate in students exchange for Indonesian students and Malaysian students. A causal-comparative research design looks into the causes of already existing differences among groups of people [24]. The causal-comparative research design fits for this study as the independent variable were not manipulated and no treatment was given to all participants. It what make a difference with the experimental research design since the causal-comparative doesn't provide any treatment to any group.

The population of the study are students who joined and did not joined SSE program. The students are at least sophomore level so there should be enough chance for them to choose joining or not joining an exchange program. The sample is composed of Indonesian representative and Malaysian representative. The Indonesian sample is the students from FSS, UNNES and the Malaysian sample is the students from FPEH, UiTM, Malaysia by using a purposive sampling technique.

The primary data will be collected from survey tests and interviews. The survey instrument, in the form of online questionnaire, will be validated through expert judgement. Questionnaire is a data collection technique which is done by giving a set of questions or written statements to respondents to be answered. The method used is a closed questionnaire [25]. The test analysis will use a quantitative descriptive analysis.

In preparing the questionnaire, indicators have been determined which will be used as the basis for compiling the questions in the questionnaire:

Table 1. Questionnaire Indicators.

\begin{tabular}{lcc}
\hline Answer choices & Score for positive statement & Score for negative statement \\
\hline Strongly agree & 4 & 1 \\
Agree & 3 & 2 \\
Disagree & 2 & 3 \\
Strongly disagree & 1 & 4 \\
Strongly agree & 4 & 1 \\
\hline
\end{tabular}


The indicators of the motivation to learn English questionnaire can be seen in the table below:

Table 2. Motivation Indicators.

\begin{tabular}{ccc}
\hline Indicator & Number of item & Total Number \\
\hline Intrinsic motivation & $1-10$ & 10 \\
Extrinsic Motivation & $11-20$ & 10 \\
& & \\
\hline
\end{tabular}

There will be 10 questions for intrinsic motivation and 10 for extrinsic motivation. The questionnaire will be consulted and validated by expert as well as tested by validity and reliability test.

The next instrument is an interview rubric. The interview intended to gain knowledge about the subjective meanings understood by the individual regarding the research topic. The interview will be conducted through zoom meeting or whatsapp video call. According to Lexy J. Moleong in [26] an interview is a conversation with specific goals. In the implementation of this research, the researcher used a semistructured interview technique which will be conducted to the respondents in two universities. The purpose of using structured interviews is to find problems in a more closed manner and do not extend from the focus of the problem.

The stages carried out for interviews, then the stages carried out by researchers in conducting interviews, namely [27]

1. Make guidelines for interview questions arranged in accordance with the formulation of the problem

2. Determine subject of the interviews, namely representatives of SSE and Non SSE UNNES students and representatives of SSE and non-SSE UiTM students.

3. Interview method via zoom or whatsapp video call

4. Record the interview and convert it in a script.

5. Ensure that the results of the interview are in accordance with the information required by the researcher

6. Analyze the results of the interview

The study uses data analysis techniques based on data that has been collected. Quantitative data will be processed using statistical analysis. The data will be explained using descriptive quantitative analysis.

\section{References}

[1] Rabinowitz, "Study Abroad Grows in Popularity, Programs and Places," Colomb. Coll. Today, vol. Winter 201, 2013.

[2] V. Berg, "Does International Student Exchange Contribute to Educating Teachers We Need in a Multicultural Society?," Intercult. Commun. Educ. Settings, vol. 3, no. 2, pp. 1-15, 2016.

[3] F. F. Lin, L. Del Fabbro, J. Needham, D. Sidwell, and J. Shaw, "Supporting culturally and linguistically diverse (CALD) undergraduate nursing students undertaking clinical placements in Australia: An exploratory qualitative study of clinical facilitator and CALD student perceptions," Nurse Educ. Today, vol. 97, p. 104712, 2021. 
[4] J. M. Fleckman, M. Dal Corso, S. Ramirez, M. Begalieva, and C. C. Johnson, "Intercultural Competency in Public Health: A Call for Action to Incorporate Training into Public Health Education," Front Public Heal., vol. 3, p. 210, 2015.

[5] B. O'Brien, D. Tuohy, A. Fahy, and K. Markey, "Home students' experiences of intercultural learning: A qualitative descriptive design," Nurse Educ. Today, vol. 74, pp. 25-30, 2019.

[6] H.-P. Wu, E. Garza, and N. Guzman, "International Student's Challenge and Adjustment to College," Educ. Res. Int., 2015.

[7] E. A. Chan, J. Y. W. Liu, K. H. K. Fung, P. L. Tsang, and J. Yuen, "Pre-departure preparation and co-curricular activities for Students' intercultural exchange: A mixed-methods study," Nurse Educ Today, vol. 63, pp. 43-49, 2018.

[8] A. Wu et al., "An International Partnership of 12 Anatomy Departments - Improving Global Health through Internationalization of Medical Education," Ann. Glob. Heal., vol. 86, no. 1, p. $27,2020$.

[9] J. Moody, "3 Benefits of Studying Abroad," 2019.

[10] T. Shulsinger, "8 Unexpected Benefits to Studying Abroad as a Graduate Student," 2017.

[11] A. W. MD, V. Maddula, and M. R. Kieff, "An online program to improve international collaboration, intercultural skills, and research knowledge," J. Dent. Educ., 2020.

[12] Sihono and F. Suraya, "11 Mahasiswa Ilmu Keolahragaan FIK UNNES KKN Antarbangsa di Malaysia," p. https://unnes.ac.id/berita/11-mahasiswa-ilmu-keola, 2019.

[13] S. Kwanboonchan and A. 2017 Committe, "Welcome Message from President of ACPES," p. http://acpes2017.kasetsart.org/, 2017.

[14] U. Team, "International Collaboration," UiTM, 2020. .

[15] F.-J. Hinojo-Lucena, I. Aznar-Díaz, M.-P. Cáceres-Reche, and J.-M. Romero-Rodríguez, "Use of social networks for international collaboration among medical students," Educ. Médica, vol. 21, no. 2, pp. 137-141, 2020.

[16] S. A.-O. Henderson, M. Barker, and J. C. Nurs, "Developing nurses' intercultural/intraprofessional communication skills using the EXCELLence in Cultural Experiential Learning and Leadership Social Interaction Maps," no. 1365-2702 (Electronic).

[17] L. McCambridge, "If you can defend your own point of view, you're good: Norms of voice construction in student writing on an international Master's programme," English Specif. Purp., vol. 54, pp. 110-126, 2019.

[18] E. Dauyah, E. Dauyah, U. Abulyatama, and A. Besar, "Jurnal Serambi Ilmu, Volume 19, Nomor 2, Edisi September 2018," Serambi Ilmu, vol. 19, no. 2, pp. 274-290, 2018.

[19] H. Imanjar, "ASEAN School Games 2019,” Tribunjateng.com, Semarang, 2019.

[20] W. Setyawati, "Inilah 20741 Calon yang Lolos Seleksi I Relawan Asian Games 2018," Pikiran Rakyat, 2018

[21] M. Raya, "Inilah Posisi Sukarelawan yang Ditawarkan di Asian Games 2018," sport.detik.com, Jakarta, 2018

[22] L. Nurrachmad and F. Suraya, "English Learning Within Sport Science Context: A Strategy to Produce Human Resources in Sports," Universitas Negeri Semarang, Semarang, 2019.

[23] T. Nagy, "English as a Lingua Franca and Its Implications for Teaching English as a Foreign Language," Acta Univ. Sapientiae, Philol., vol. 8, Dec. 2016.

[24] J. R. Fraenkel and N. E. Wallen, "How to Design and Evaluate Research." p. 642, 2012.

[25] A. Kurbani, "Pengaruh Kualitas Layanan Akademik Dan Fasilitas Pendidikan Terhadap Kepuasan Mahasiswa Kuliah pada Universitas PGRI Palembang," J. Media Wahana Ekon., vol. 13, no. 4, p. 23, 2017.

[26] A. N. Yuhana and F. A. Aminy, "Optimalisasi Peran Guru Pendidikan Agama Islam Sebagai Konselor dalam Mengatasi Masalah Belajar Siswa," J. Penelit. Pendidik. Islam, vol. 7, no. 1, p. $79,2019$.

[27] G. T. Henry, K. C. Bastian, and A. A. Smith, "Educational Researcher," 2012. 